\title{
6
}

\section{Accessing the Archives of the Australian War Crimes Trials after World War II}

\author{
Narrelle Morris
}

\section{Introduction}

In 1945-51, Australian Military Courts convened 300 trials of Japanese accused of committing various war crimes during World War II, which sat at Morotai, Wewak, Labuan, Darwin, Rabaul, Singapore, Hong Kong and Manus Island. The military courts were creatures of statute under the War Crimes Act 1945 (Cth) and akin to field general courts-martial. ${ }^{1}$ As such, they were exercising executive, not judicial, power. Significantly, the military courts had no duty to produce written reasons for decisions. ${ }^{2}$ It is the lack of written decisions that elevates the trial proceedings - tens of thousands of pages of forms, transcripts and exhibits that were created during the trials- to a position of unusual importance as legal records. Moreover, there was some recognition at the time that the proceedings had worth beyond legal records; they formed a body of historical records relating to the war in their own right and merit and with national, if

1 See Michael Paes, 'The Australian Military Courts under the War Crimes Act 1945-Structure and Approach' in Georgina Fitzpatrick, Timothy McCormack and Narrelle Morris (eds), Australia's War Crimes Trials 1945-51 (Brill Nijhoff, 2016) 103-33, doi.org/10.1163/9789004292055_005.

2 Even in judicial proceedings, the requirement to give reasons is regarded as a normal but not universal incident' of the process: Public Service Board (NSW) v Osmond (1986) 159 CLR 656, 667. 
not international, significance. The proceedings contain thousands of accounts of war crimes perpetrators, victims and witnesses, as well as firsthand accounts of military service, movements, battles, capture by the enemy and, inevitably, atrocities. In seeking to gain copies of the proceedings, the Australian War Memorial asserted in 1946, for example, that they would be of 'great value to the official historians, and later to other historians and students of the Second World War'. ${ }^{3}$ However, the Department of the Army, which had been responsible for the trials, simply treated the proceedings as it did those of courts-martial. The proceedings were regarded as classified and confidential Commonwealth legal-administrative records that were shuffled between government departments and eventually archived but were closed to public access for the next quarter of a century.

Australia's tight control of its trial proceedings in the postwar period was not unusual for government records in this period. This was due to both the absence of an independent archive and the tendency to regard archiving as an economically effective means for the storage and disposal of records, rather than as the creation of a valuable national repository to preserve and make information accessible. However, given the obvious personal and international character of the trial proceedings and associated war crimes records, the closure raises questions about access to information for those prosecuted and their country. Australia provided only a 'bare minimum' ${ }^{4}$ of information to Japan about the trials, mostly concerning the identities of the convicted and their sentences. Thus, the Japanese Government made several diplomatic requests to Australia in the 1950s and 1960s for access to or copies of the trial proceedings and other war crimes records. Other Allied nations were receiving similar Japanese requests for their war crimes records. The consequent Allied consultation was fairly rudimentary but demonstrated that a consensus approach to the requests was thought necessary.

These processes revealed that, in the decades after the war, Allied nations were generally opposed to making their war crimes records available, although some countries were slightly more permissive than others. In Australia, the issue of granting Japanese access to records was typically

3 AW Bazley, Acting Director, Australian War Memorial to the Secretary, Department of External Affairs (Ext Aff), 28 August 1946, National Archives of Australia (NAA): MP742/1, 336/1/1000.

4 As characterised by Yuma Totani, Justice in Asia and the Pacific Region, 1945-1952: Allied War Crimes Prosecutions (Cambridge University Press, 2015) 186, doi.org/10.1017/CBO9781316104118. 
regarded as one of 'policy and practicability, rather than of law'. 5 There was no legal requirement to provide the trial proceedings even to those who had been prosecuted, let alone to Japan. Thus, citing policy and practicability, the Departments of External Affairs and the Army refused to release the records for decades. The policy reasons for access refusal usually turned on what was seen as Australia's right and obligation to control the dissemination of sensitive 'national' information that Japan might use to criticise the trials. Moreover, the estimated expenses in time and money to make copies of these records was used to argue that their provision was impracticable. Little consideration in this decision-making process was given to those who may have had a valid interest in access to the records or to the light that the records may have shed on a key part of wartime history. The closure of the records simply ensured that Australia maintained an exclusive grip on knowledge of that history.

Drawing on government correspondence, this chapter examines the postwar views and control of Australia's archives of war crimes records in response to the Japanese requests for access. This story will be told through short vignettes that describe the shifting relationships between Australia and Japan, as much as those between the institutions of the Australian Government and their conceptualisation and approach to the value and materiality of war records. This story demonstrates how records that documented the prosecution and punishment of people from another nation during legal processes that were open to the public to watch (prima facie court records) can, nonetheless, be classified afterwards as confidential national records (not court records) of such significant international political consequence that they had to be zealously protected for decades. Although Prime Minister John Gorton announced the accelerated release of general World War II records in $1971,{ }^{6}$ it took until 1975 for the trial proceedings to be opened to the public. In an interesting turn of fate, it was the Commonwealth's legal executive-the AttorneyGeneral's Department - that finally recognised the importance to history of allowing public access to the records, an importance that overrode any supposed protective requirements, such as confidentiality. The 'past', stated

5 See handwritten note to Mr Horne, 28 May 1965, NAA: A1838, 3103/10/13/2 PART 15A.

6 Access to Commonwealth Archives - Statement by the Prime Minister, Mr. John Gorton (30 December 1970) Department of the Prime Minister and Cabinet <http://pmtranscripts.pmc.gov.au/sites/default/ files/original/00002342.pdf>. 
Attorney-General Keppel Enderby QC, 'should be everyone's property'. Yet, the lengthy delay in making the records accessible meant that, in the interim, most individuals involved in the trials had died, taking with them what could have been invaluable personal accounts and permanently impacting on our understanding of the trials and the histories that can be told of them. In hampering research for so long, protectionism had, in this case, an indelible effect on knowledge.

\section{The First Japanese Request for Access in 1955}

Japan's first request to the Department of External Affairs for records relating to Japanese war criminals and their trials arrived in 1955, four years after the final trial on Manus Island. A Japanese Embassy official asked in person for information about the whereabouts of the records and what authority was in charge of them; whether there were extra copies of these records; and whether Australia would consent to Japan obtaining these copies. Given that the official also enquired about the estimated cost of reproducing the records, it was perhaps contemplated that Japan would pay an appropriate fee. ${ }^{8}$

As the Army had convened the trials, External Affairs forwarded the Japanese request to the Department of the Army for its view. ${ }^{9}$ The Secretary of the Department of the Army was surprised that a 'request of such magnitude' had been made orally. He advised that it seemed 'almost certain that the information is wanted for propaganda purposes as no other possible reason can be visualised'. He observed that '[p]ublication of distorted versions of particular trials, extracts therefrom taken out of context, or half truths' might assist the various nationalist organisations that had since sprung up in Japan, which sought, for example, to 'restore the lost honour of the Imperial armed forces' and to 'correct the cruel injustices done to their dignity and memory'. He pointed out that there was nothing in the War Crimes Act or its regulations that provided for copies of the proceedings to be made available and nor were there extra

7 Attorney-General (Att Gen) press release, 'Access to Historical Records', 2 June 1975, NAA: A1838, 3103/10/13/12 PART 16A.

8 Secretary, Ext Aff to the Secretary, Department of the Army (hereafter Army), 8 July 1955, NAA: A1838, 3103/10/13/2 PART 13.

9 Ibid. 
copies. He estimated that it would cost $£ 13,000$ and '20 typist years' to retype about 75,000 pages of records or $£ 38,500$ and ' 185 machine days' to do photostatic reproductions and his departmental staffing was insufficient to undertake such a 'tremendous' task. For all these reasons, he recommended that no records should be made available to the Japanese. ${ }^{10}$

External Affairs considered the Army's response and canvassed a number of high-level departmental officials. James Plimsoll, then Assistant Secretary, for instance, recommended that Japan should be told that it was not possible to provide any records and that no information should be provided at all, apart from the Army's estimated cost of reproduction. ${ }^{11}$ In due course, the Japanese Embassy was told that that none of the information requested could be made available. The Embassy apparently made 'no comment' on the refusal. ${ }^{12}$

After Australia's refusal was communicated to Japan, External Affairs informed its diplomatic representatives in the United States, the United Kingdom, the Netherlands, France and the Philippines about the request and the refusal. The representatives were asked to ascertain whether Japan had made similar requests to those nations; if so, what that government's response had been; and if there were any 'views' as to what was 'behind' the request. The Australian Embassy in Tokyo was similarly asked to 'shed any light' on what had prompted the request. ${ }^{13}$ The Embassy responded that '[n]othing specific' had suggested itself as the 'immediate cause' of the request, but that it seemed 'likely' that the records were sought to give 'further support for appeals for clemency'. ${ }^{14}$ Most of the other Allied Powers had, in fact, received Japanese requests for access to, or copies of, their records of war crimes trials. The cautionary responses were fairly similar in each case, demonstrating scepticism of the Japanese motives. As a result, the requests were met usually with outright refusals or with limited access being offered with such stringent conditions and/or high costs to be met by Japan that such offers were not taken up. The United States, for example, had received a Japanese request for records, but the

10 AD McKnight, Secretary, Army to the Secretary, Ext Aff, attaching Appendix A and B, 21 July 1955, NAA: A1838, 3103/10/13/2 PART 13.

11 Handwritten note signed and dated 27 July 1955, NAA: A1838, 3103/10/13/2 PART 13.

12 Secretary, Ext Aff to the Secretary, Army, 12 September 1955, 1, NAA: A1838, 3103/10/13/2 PART 13.

13 TW Eckersley for the Secretary, Ext Aff, to Washington, London, The Hague, Paris, Manila and Tokyo, 1 August 1955, NAA: A1838, 3103/10/13/2 PART 13.

14 RWL Austin, Second Secretary, Australian Embassy, Tokyo to the Secretary, Ext Aff, 2 September 1955, NAA: A1838, 3103/10/13/2 PART 13. 
State Department could 'only guess' what the reason for it might be, as none had been provided. ${ }^{15}$ State Department officials suggested to the Australian Embassy that the Japanese 'might wish to use parts of the ... records to support requests for the release of prisoners' or, alternatively, that the Japanese 'simply' wanted 'all records concerning important matters in which its nationals have been or may be concerned'. ${ }^{16}$ One of these officials, legal expert George Hagan, referred to:

the common Japanese feeling that the war criminal trials constituted a kind of national disgrace and the Japanese desire to 'expunge them', as it were, from the record: possession of the official documents might help them in some way for this purpose. ${ }^{17}$

The State Department told the Australian Embassy in early 1956 that the Japanese Embassy was going to be informed that the records were not available', since they were still being used by the US Clemency and Parole Board relating to war criminals. Moreover, ' $[\mathrm{s}]$ ome form of words will be found' to 'discourage the Japanese from renewing their application', even after the war criminals had been all released. ${ }^{18}$ As External Affairs later characterised the overall outcome of the Japanese requests to the Allied Powers, '[i]n effect, the Japanese got no change from anybody'. ${ }^{19}$

\section{The Second Japanese Request for Access in 1959}

The second, quite similar, Japanese request for copies of Australian records arrived in August 1959. The Japanese Embassy advised that the Ministry of Justice was 'engaged in collecting' all postwar trial records. ${ }^{20}$ Indeed, the Ministry had established a Judiciary and Legislation Investigation Bureau (shihō hösei chōsabu) in May 1958, tasked with the project to collect as many

15 JR Rowland, First Secretary, Australian Embassy, Washington DC to the Secretary, Ext Aff, 29 August 1955, NAA: A1838, 3103/10/13/2 PART 13.

16 Ibid.

17 Ibid.

18 JR Rowland, First Secretary, Australian Embassy, Washington DC to the Secretary, Ext Aff, 25 January 1956, NAA: A1838, 3103/10/13/2 PART 14A.

19 Ext Aff File Note, 'Japanese War Criminals, Records', 7 September 1959, NAA: A1838, 3103/10/13/2 PART 15A.

20 Embassy of Japan, Note Verbale, no. 109, 25 August 1959, NAA: A1838, 3103/10/13/2 PART 15A. 
Allied trial records as possible. ${ }^{21}$ One External Affairs analyst was initially minded to reject the request outright, as Japan had provided 'even fewer reasons for the request now than they did in 1955, when we rejected it' and that the reasons for the rejection remained valid. ${ }^{22}$ The analyst posited that the request was based on the fact that 'there is, in Japan, pressure to "correct" the verdicts of Allied Military Tribunals". ${ }^{23}$ The analyst also suggested that if none of the above was sufficient to explain a rejection, Japan could be told that it was based on 'the need to protect individuals who had supplied information about war crimes'. ${ }^{24}$ The Legal and Treaty Division of External Affairs also advised that there was 'no obligation in law' to comply with the request and, in fact, no specific legislative provision under which the records could be provided. ${ }^{25}$ However, this did not prevent the handing over of copies to Japan, if this was the policy decision that was made. ${ }^{26}$ The Department of the Army agreed that the objections raised in 1955 remained 'sufficient' to refuse the request and, if any further reason was required, it was the ongoing Allied opposition to providing access. The Army suggested that the Japanese Embassy simply 'be informed that it is not the practice of Australia to pass documents of this nature to a foreign Government or to provide copies of them. ${ }^{27}$

This time, External Affairs began international consultation while consideration was ongoing. ${ }^{28}$ The United States advised that another Japanese request had arrived in mid-1959, for the stated reason that Japan wanted the records 'for the purpose of historical record'. However, a State Department official suggested to an Australian official that if Japan gained the records, it 'might in the future attempt to cast doubt on the trials' and that 'this was the real motivation' in seeking them. The State Department intended to 'stall the Japanese request indefinitely by long drawn-out consultation' with other government agencies. The only 'difficulty' was

21 Totani, above n 4, 188.

22 Ext Aff File Note, 'Japanese War Criminals' Records', 7 September 1959, NAA: A1838, 3103/10/13/2 PART 15A.

23 Ibid.

24 Ibid.

25 AH Body, Ext Aff File Note, 'Japanese War Criminals' Records', 15 September 1959, NAA: A1838, 3103/10/13/2 PART 15A.

26 Ibid.

27 B White for the Secretary, Army to the Secretary, Ext Aff, 3 March 1960, NAA: A1838, 3103/10/13/2 PART 15A.

28 HA Dunn for the Secretary, Ext Aff to the Australian Embassy-Washington, the Hague, Paris, Tokyo and the Australian High Commission, London, 5 July 1960, NAA: A1838, 3103/10/13/2 PART 15A. 
that 'some' proceedings had already been reproduced for university libraries. Therefore, the State Department expected that it might have to permit Japan to have copies of those trials, although it was likely that access would be refused to investigation files. ${ }^{29}$ Of the other Allied countries, the United Kingdom, the Netherlands and France had also received Japanese requests but were generally not cooperative. Nevertheless, France had provided to Japan a list of the numbers and dates of the judgments of 34 Japanese war criminals and advised that it would provide copies only of judgments if Japan paid the expense of doing so. ${ }^{30}$

After receiving the international responses, External Affairs continued to debate the matter. One official suggested that it would 'close the matter out to refuse the Japanese request', which he favoured..$^{31}$ Another official felt 'strongly that we should not yield an inch on the subject of war criminals', given that 'Japan's record in this field was disgusting' and that it would be 'abhorrent to the Australian people if it became known that we even discussed this subject with the Japanese'. Moreover, this official suggested that Japan be told that 'we would not welcome any further approaches on this subject'. ${ }^{32}$ Another official agreed with this latter view, pointing out in particular that 'we have already done a lot of yielding' on war criminal issues. ${ }^{33}$

The Australian Embassy in Tokyo was warned in advance that the Japanese request would be refused and was advised that the grounds for the refusal included Australia's 'feeling that we have gone far enough in meeting other Japanese requests on such matters as remission of sentences of war criminals ${ }^{34}$ On 19 December 1960, Assistant Secretary DW McNicol advised Mr Yoshida, the Counsellor at the Japanese Embassy, that:

29 Australian Embassy, Washington, to the Minister and Ext Aff, 1 August and 3 August 1960, both in NAA: A1838, 3103/10/13/2 PART 15A.

30 GJ Price, Second Secretary, Australian Embassy, Paris to the Secretary, Ext Aff, 23 September 1960, NAA: A1838, 3103/10/13/2 PART 15A.

31 Handwritten note for Mr McNicol, 24 November 1960, NAA: A1838, 3103/10/13/2 PART 15A.

32 Ext Aff File Note for Mr Heydon, 25 November 1960, NAA: A1838, 3103/10/13/2 PART 15A.

33 Ibid.

34 DW McNicol, Assistant Secretary, Ext Aff to the Australian Embassy, Tokyo, 2 December 1960, NAA: A1838, 3103/10/13/2 PART 15A. 
The Department wishes to inform the Embassy that it is not the practice of the Australian Government to make available information relating to documents of this nature and it is therefore unable to meet the Embassy's request. ${ }^{35}$

McNicol told Yoshida that it was in Japan's interests that memories of war crimes - which had 'deeply shocked and angered the Australian people'be 'erased' and that the 'chances that time would diminish the memories would be improved if one was not reminded of these crimes' ${ }^{36} \mathrm{McNicol}$ added, on a personal level, that it would be 'preferable' if the Japanese Ministry concerned was 'persuaded not to raise the subject of war crimes again'. ${ }^{37}$ Yoshida said that he was 'grateful' for the reply and 'understood' ${ }^{38}$

After Australia's refusal, the United States surprised Australia in May 1961 with the information that it proposed to tell Japan that copies of its trial records - not its investigation records, which remained classifiedcould be made available at Japan's expense. The reasoning behind this abrupt change in position was that, as the Japanese had participated in the trials, they could be 'assumed to have their own rudimentary records' of them. In addition, records had already been partially made available in the United States. The State Department had also concluded that request arose from 'Japanese Bibliophile-type psychology and their passion for completeness'. While the State Department continued to 'bear in mind' the possibility that Japan might want the records to 'enable' the casting of doubt on the trials and to 'attempt to rewrite history', Japan was already in a position to do this. Therefore, Australia, the United Kingdom and the Netherlands were invited to give their views to determine whether an 'agreed policy could be worked out', so as to 'avoid' Japan using the United States' position to 'bring pressure to bear on the others' ${ }^{39}$

External Affairs forwarded the United States' proposal to the Army, which repeated its opinion that Japan should be refused access. ${ }^{40}$ The Australian Embassy in Washington was advised in December 1960 that Australia was

35 Ext Aff Record of Conversation with Mr Yoshida by Mr DW McNicol, 'Japanese Request for Records Relating to War Crimes Trials', 19 December 1960, NAA: A1838, 3103/10/13/2 PART 15A.

36 Ibid.

37 Ibid.

38 Ibid.

39 Australian Embassy, Washington to Ext Aff, 3 May 1961, NAA: A1838, 3103/10/13/2 PART $15 \mathrm{~A}$.

40 B White, Secretary, Army to the Secretary, Ext Aff, 26 May 1961, NAA: A1838, 3103/10/13/2 PART 15A. 
adhering to its refusal and hoped that the United States would 'not act unilaterally', given that there were 'advantages' to 'maintaining a united front on this issue'..$^{41}$ External Affairs in London passed along the comment that the United States' proposal had led a senior Foreign Office official to refer 'unkindly to the "double-crossing" attitude of the Americans'. ${ }^{42}$ External Affairs later assumed that it was continued Australian and United Kingdom opposition that led the United States to reconsider its plan to provide its trial records to Japan. ${ }^{43}$ Instead, the United States released a policy directive on war crimes records in March 1963, which stated the details of the trial records that could be made available to American citizens upon application; however, the trial records were not available to Japan or Japanese citizens. Moreover, apart from official purposes, war crimes investigation records were 'closed to all persons'. ${ }^{44}$

\section{The Third Japanese Request for Access in 1965}

That the Japanese had not been discouraged by lengthy delays in responding to the requests for war crimes records and the repeated firm refusals to provide the records, as well as the advice to desist from requesting them, was made clear in April 1965, when another request arrived via the Japanese Embassy. The request came with strong reassurances about the purposes for which Japan wanted the copies and the conditions it was willing to abide by to receive them. The Ministry of Justice explained that it was collecting 'all available material concerning war trials' to facilitate research on the factors such as the social system that 'contributed to war crimes', the 'legal aspects of the prosecutions' and the 'procedural rules', which it was convinced would 'contribute to the development of international law and to the prevention of war'. The Ministry reassured Australia that it had 'no intention of repudiating the war trials themselves'

41 Ext Aff to the Australian Embassy, Washington, repeated to London and The Hague, 29 May 1961, NAA: A1838, 3103/10/13/2 PART 15A.

42 H Marshall for Senior External Affairs Representative, London to the Secretary, Ext Aff, 9 June 1961, NAA: A1838, 3103/10/13/2 PART 15A.

43 Ext Aff File Note by AJ Melhuish for Mr Horne, 'Japanese War Crimes', 13 May 1965, NAA: A1838, 3103/10/13/2 PART 15A.

44 Detailed in RN Birch, Counsellor, Australian Embassy, Washington to the Secretary, Ext Aff, 17 September 1965, NAA: A1838, 3103/10/13/2 PART 15A. 
and advised that any copies would be held at the Ministry and 'made available only to those scholars who can make good use of them for a purely academic purpose'. ${ }^{45}$

An initial External Affairs analysis of the Japanese request concluded that the 'reasons advanced by the Japanese' were 'not very compelling. ${ }^{46}$ Therefore, it was suggested that the request be refused with the same terse statement that had been given five years earlier. ${ }^{47}$ However, the usual consultation with the Department of the Army revealed that while the Army maintained its opinion that the records should not be provided, it conceded that it was 'now twenty years since the war' and that it would be 'increasingly difficult to sustain this attitude as time goes on' ${ }^{48}$ Change also appeared to be in the air at External Affairs: Malcolm Booker, a senior official and former ambassador, suggested in October 1965 that the department should take 'a fresh look at our negative attitude' and 'ease up a bit'. In his view, Australia's approach had become 'anachronistic' and, he alleged, out of step with that of the United States, which was 'prepared to make open to the study of all persons [sic] trial records, transcripts, documents and other evidence presented in court'. ${ }^{49}$ Unfortunately, this was a clear misreading of the United States' policy. While the United States had by then allowed Japan access to its records of the International Military Tribunal for the Far East (IMTFE), its own trial records remained closed as per the 1963 directive. Despite the inaccurate premise, Booker's suggestion to reconsider Australia's approach was adopted.

A draft briefing memorandum was prepared for the Minister for External Affairs Paul Hasluck, which provided the background of the 1955, 1959 and 1965 requests and advised that as 'twenty years have now passed since the end of the war it is considered that a completely negative attitude to the Japanese request is anachronistic and that we might modify our attitude. ${ }^{50}$ The draft memorandum conceded, accurately, that the United States had only made publicly available the records of the IMTFE,

45 Embassy of Japan, Note Verbale, no 51, 25 April 1965, NAA: A1838, 3103/10/13/2 PART 15A.

46 Ext Aff File Note by AJ Melhuish for Mr Horne, 'Japanese War Crimes', 13 May 1965, NAA: A1838, 3103/10/13/2 PART 15A.

47 Ext Aff File Note for Mr Booker, 'Japanese War Crimes', 7 October 1965 attaching draft note verbale addressed to the Embassy of Japan, NAA: A1838, 3103/10/13/2 PART 15A.

48 B White, Secretary, Army for the Secretary, Ext Aff, 18 August 1965, NAA: A1838, 3103/10/13/2 PART 15A.

49 Ext Aff File Note by LE Phillips for Mr Piper, 'Japanese War Crimes', 14 October 1965, NAA: A1838, 3103/10/13/2 PART 15A.

50 Draft for the Minister, 'Japanese War Crimes', nd, 3, NAA: A1838, 3103/10/13/2 PART 15A. 
but argued that that there was 'no real argument against enlarging the permission' to include national records. It recommended to the Minister that Japan be granted access to Australia's records. ${ }^{51}$

Before Hasluck was given the briefing memorandum, External Affairs sought further information from the United States. This time, the State Department was slightly more revealing about the reasons for its historical reluctance to release the records. The State Department told the Australian Embassy that all the records had been 'bundled together in Army warehouses' and that the 'initial U.S. reluctance to release' the records arose from the 'physical problem of sorting the material'. ${ }^{52}$ Then, around 1956, the 'records were handed over to the archivists' and it was 'feared' that 'some of the material inadvertently found its way into the hands of research scholars'. ${ }^{53}$ This fear had prompted a discussion about access restrictions and had led to the decision that the records should not be released to Japan unless the other Allied nations were similarly prepared to acquiesce, which they were not. This was the policy still being observed in 1965. However, the State Department was now tending to "discount any possibility that the Japanese are attempting to "whitewash" criminals at this point of history'. Rather, the State Department assumed that 'some obscure [Japanese] historical section has discovered gaps in its files and succeeded in having its request processed by the Foreign Ministry'. ${ }^{54}$

Australia's decision on Japan's request was still being considered in early 1966 when it was proposed that, subject to widespread agreement, copies of the trial decisions should be offered to Japan..$^{55}$ Acting Legal Advisor Patrick Brazil recommended that as George Dickinson-who had been the defence advisory officer at the Manus Island trials in 1950-51-had praised in print the 'ability and fairness' of President Kenneth Townley, who presided over the Manus Island trials, ${ }^{56}$ it might be worth considering that:

51 Ibid.

52 RN Birch, Counsellor, Australian Embassy, Washington to the Secretary, Ext Aff, 10 December 1965, 1, NAA: A1838, 3103/10/13/2 PART 15A.

53 Ibid.

54 Ibid.

55 Ext Aff File Note by HW Bullock for Mr Booker, 'Japanese War Crimes', 8 February 1966, NAA: A1838, 3103/10/13/2 PART 15B.

56 George Dickinson, 'Manus Island Trials' (1952) 38 Journal of the Royal Australian Historical Society 67; George Dickinson, 'Japanese War Trials' (1952) 24 The Australian Quarterly 69. 
if judgments are to be made available, they should be limited, at this stage at least, to the judgments given in the Manus Island trials. This course would have the advantage of limiting the work involved in sorting out the records and would also mean that we could reasonably be confident as to the quality of the jurisprudence that we were putting before the eyes of our Japanese friends. ${ }^{57}$

Thus, External Affairs suggested to the Army that departmental officers examine the Manus Island decisions to determine whether their 'contents would cause difficulties if made available to the Japanese authorities. ${ }^{58}$ However, what this process revealed was that External Affairs was completely unaware of the fact that the trials had no written decisions that could be provided. Even the Army, which had run the trials, now appeared unaware of this crucial fact, as it did not correct External Affair's impression but simply said that the decision was 'properly' one for External Affairs. ${ }^{59}$ Thus, External Affairs remained under the impression throughout the remainder of 1966 that the Army was busily engaged in reviewing the (non-existent) decisions from the Manus Island trials. Booker was told in August 1966, for example, that despite several reminders to the Army, External Affairs was 'waiting for Army to examine the judgments [sic]'. ${ }^{60}$

External Affairs must have finally realised its misapprehension about the existence of written decisions, as a review of the trial proceedings commenced. Lyndel Prott of the Legal and Treaties Branch observed in her April 1967 report that the trials were 'generally satisfactory' and did not cause 'any substantial miscarriage of justice'. However, she pointed out that:

since war crimes trials are a controversial issue in general, they provide material for a troublemaker to use against the country which conducted them ... Almost all of the trials of ' $\mathrm{B}$ ' and ' $\mathrm{C}$ ' class criminals have elements appearing on the face of the records which would provide a hostile reader with anti-Australian ammunition. ${ }^{61}$

57 Ext Aff File Note by P Brazil, Acting Legal Officer, 'Japanese War Crimes Trials', 11 March 1966, 2, NAA: A1838, 3103/10/13/2 PART 15B.

58 AH Borthwick, Acting Assistant Secretary, Ext Aff to the Secretary, Army, 17 March 1966, NAA: A1838, 3103/10/13/2 PART 15B.

59 B White, Secretary, Army to the Secretary, Department of Defence, copied to the Ext Aff, 22 March 1966, NAA: A1838, 3103/10/13/2 PART 15B.

60 Ext Aff File Note by AH Borthwick for Mr Booker, 'Japanese War Crimes', 23 August 1966, NAA: A1838, 3103/10/13/2 PART 15B.

61 Lyndel V Prott, 'Release of Records of Japanese War Crimes Trials', 5 April 1967, 1, 2, 5, NAA: A1838, 3103/10/13/2 PART 15B. 
Prott concluded that Australia should 'be wary of providing adverse propaganda against ourselves', but pointed out that a refusal to grant access to the trials 'might imply that we have something to hide'. ${ }^{62}$ Afterwards, Prott studied reports on the American, British, Dutch, French and Chinese war crimes trials and observed that 'at least some' of our trials could 'raise no more criticism than that which has already been thoroughly discussed' and that any impact could be 'diminished' by the fact that criticism could be levelled widely. In any event, she thought that it was possible to select certain trials for provision to Japan that were defensible against criticism. ${ }^{63}$

By this stage, a clearer division had appeared within External Affairs as to whether the Japanese request should be granted. The department's East Asia Branch, for instance, felt that Australia's agreement would further relations with Japan, but the Legal and Treaties Branch was opposed. Two draft briefing memoranda that presented lists of 'considerations' for and against the release of Australia's trial records, noticeably so in that specific order, were prepared. The considerations against release in the first draft were:

(i) hostile consideration of these records by the Japanese could lead to criticism of the trials and create unpleasant propaganda if made public;

(ii) a future government may attempt to repudiate these trials (although the present government says it has no intention of doing so);

(iii) their study would draw attention to provisions of the War Crimes Act which would be better left in their present happy state of neglect;

(iv) once the records were transferred we would have no further control over their use or future disposal by the Japanese;

(v) the release of certain cases or of certain parts of proceedings only may incite the Japanese to further demands;

(vi) in the absence of judgments the trial records of little value for research $\left[\right.$ sic]. ${ }^{64}$

The considerations promoting release generally revolved around being 'obliging' to the Japanese Government, with whom relations were 'likely to become of increasing importance', or avoiding the suggestion that

62 Ibid $1,11$.

63 Ext Aff File Note by Lyndel V Prott, 'Release of Records of Japanese War Crimes Trials', 14 June 1967, NAA: A1838, 3103/10/13/2 PART 15B.

64 Draft for the Acting Minister, 'Japan—War Trial Records', nd, 1-2, NAA: A1838, 3103/10/13/2 PART 15B. 
Australia had something to hide or distrusted Japan or its motives. ${ }^{65}$ The second draft memorandum was more vehemently against releasing the records. It pointed out that as redeeming Japan's reputation was presumably part of the overall goal, 'critical attention' would necessarily be focused on 'debatable aspects' of the trials. ${ }^{66}$

External Affairs consulted again with the Australian Embassy in Tokyo. Counsellor RJ Percival responded that he thought that the undertakings provided by Ministry of Justice about how the records would be used should not be taken seriously. He pointed out:

If at some future date the Japanese authorities wish to repudiate any or all of the war crimes trials, question any particular sentences, criticise the conduct of the trials, or take any similar action, we can be fairly sure that they will not let any previous undertakings of this sort stand in their way. ${ }^{67}$

He conceded that, at this point, he saw 'little gain' for the Japanese Government in doing so. On the other side, Percival pointed out that it would not help Australia's relations with Japan to be 'the only government to hold out on this matter' or for Japan to become aware that, 'but for our opposition', other Allied nations would have provided their records. He also thought that refusing the request would suggest that Australia had something to hide and that this would be 'evidence that a strong element of distrust and antipathy remains in Australia's attitude towards Japan'. In his opinion, Japan would 'keep at us for the release of these records until such time as we agree to their transfer'. Therefore, he suggested that Australia release its records, provided the other Allied nations also agreed to do so. ${ }^{68}$

After further consultation with the other Allied Powers, another draft briefing memorandum was prepared for the Minister for External Affairs in July 1968. The Minister was asked to approve the records' release upon the release by the United States of its records. ${ }^{69}$ When consulted, the Army now indicated that there was 'no reason' why the Australian records could

65 Ibid 2.

66 GA Jockel for the Acting Minister, 'Japan—War Trial Records', nd, 1, NAA: A1838, 3103/10/13/2 PART 15B.

67 RJ Percival, Counsellor, Australian Embassy, Washington to the Secretary, Ext Aff, 26 June 1967, 1, NAA: A1838, 3103/10/13/2 PART 15B.

68 Ibid 2.

69 MR Booker, 'Japan—Release of Australian War Trial Records', 12 July 1968, NAA: A1838, 3103/10/13/2 PART 15B. 
not be 'perused' by Japan, apart from those of two particular trials, which it identified. In those two trials, the Judge-Advocate General (JAG) had advised not to confirm the findings but his advice had been disregarded. ${ }^{70}$ However, the Army pointed out that the JAG's reports were 'never included' when transcripts of courts-martial were made available, as they were regarded as 'confidential and privileged'. ${ }^{71}$ The Attorney-General's Department then agreed in principle to release the trial proceedings to Japan, subject to the JAG's reports being withheld. ${ }^{72}$

Thus, External Affairs recommended to the Minister that, subject to the concurrence of the Minister of Defence, the trial proceedings (apart from the JAG's reports) be approved for release in parallel with the release of the United States records. ${ }^{73}$ In response, Hasluck raised a crucial issue of parity: should Australia release the records to Japan 'for the use of scholars', as Japan had proposed, without 'facing up' to the issue of releasing them to Australian scholars? ${ }^{74}$ Booker advised Hasluck that the records had been withheld from Australian scholars on the 'grounds that information they might derive from them could come into the hands of the Japanese to whom the records have been barred'. Booker's reasoning might have been constructed on the spot, as External Affairs had told the State Department only the previous year that there was 'no record of any interest ever being expressed by scholars' in the Australian trial records. ${ }^{75}$ This lack is not really surprising, as scholars would have been unlikely to have directed requests for access to External Affairs, given that the records had been created by the Army and, once archived in the Commonwealth Archives Office, were controlled by the Attorney-General's Department. Certainly, political scientist and historian David Sissons, who had served as an interpreter at the Rabaul trials, had been seeking access to various war crimes records since the early 1950s but his queries were directed, for

70 For these two trials, see NAA: A471, 80757 and 81068.

71 B White, Secretary, Army to the Secretary, Ext Aff, 25 July 1968, NAA: A1838, 3103/10/13/2 PART 15B.

72 Secretary, Att Gen to the Secretary, Ext Aff, 15 August 1968, NAA: A1838, 3103/10/13/2 PART 15B.

73 MR Booker, 'Japan—Release of Australian War Trial Records', 12 July 1968, 4 September 1968, NAA: A1838, 3103/10/13/2 PART 15B.

74 MR Booker, 'Japan—Release of Australian War Trial Records', 5 September 1968 with marginalia on 4, NAA: A1838, 3103/10/13/2 PART 15B.

75 Ext Aff to the Australian Embassy, Washington, 11 April 1967, NAA: A1838, 3103/10/13/2 PART 15B. 
example, to the Australian War Memorial. ${ }^{76}$ Regardless of past reasoning, Booker then suggested to Hasluck that if the records were released to Japanese scholars, they should 'also be made available to bona fide Australian scholars'. ${ }^{77}$ In support, he pointed out that if Japanese scholars 'distorted or otherwise misused the records, their interpretations would be open to comparison with the judgments of Australian scholars' ${ }^{78}$ Hasluck eventually approved the recommendation to release the records, subject to the proviso that the release go no further, as 'we have to keep in step with the Allies as much as we can and not get ahead of them'. ${ }^{79}$

Although Australia had finally, after three years, made a decision on the Japanese request, the process of consultation continued without any communication of that decision to Japan. Various concurrences to releasing the records were still required, including those of the United States and the United Kingdom. In the interim, there were other practicalities to address, including whether a ministerial or other committee had to approve the release, given that it was a 'sort of archives policy matter'. ${ }^{80}$ Whether all the records were in existence and accessible, how to offer Japan access and the costs of doing so also had to be ascertained. It was also suggested that the Returned Services League and the Australian War Memorial be 'sound[ed] out' on the release in case of 'any political backlash from old soldiers' ${ }^{81}$

All of this background process was presumably underway when the issue of access to the trial records was finally publicised in mid-1969. Jack Sue, a former member of $Z$ Special Force on Borneo, asked the Army for access to the trials that dealt with the Sandakan-Ranau 'death' marches to complete his book. ${ }^{82}$ Making the Australian Government appear as if it was being churlish to a veteran, a Canberra Times story alleged that Sue had been given 'unqualified refusals' to access the files for 17 years, which

76 Letter from David Sissons to the Director, War Memorial, 27 December 1954, AWM: AWM315, 449/009/142.

77 Underlining in the original: Ext Aff File Note by MR Booker for the Minister, 'Japan-Release of Australian War Crimes Records', 25 November 1968, 1, NAA: A1838, 3103/10/13/2 PART 15B.

78 Ibid, 2.

79 Additional copy of draft submission for the Minister by MR Booker, 'Japan—Release of Australian War Trial Records', 5 September 1968, with marginalia dated 26 November 1968 on 4, NAA: A1838, 3103/10/13/2 PART 15B.

80 Ext Aff File Note for Mr Borthwick, 2 January 1969, NAA: A1838, 3103/10/13/2 PART 15B.

81 Ibid.

82 Jack W Sue to the Minister of the Army, 3 June 1969, NAA: A1838, 3103/10/13/2 PART 15B. 
had delayed publication of his book since $1952 .{ }^{83}$ At this point, External Affairs had not yet determined how to decide whether any applicant for access was a bona fide scholar, but it advised that it had no objection to Sue perusing the records, provided that 'no reference' was made in the book to 'the records as such or to the fact that he has been given access to them'. This condition was imposed because no international concurrence to the release of records had yet been received. ${ }^{84}$

Amply displaying the problem with consultative and consensus decisionmaking involving multiple stakeholders, and the apparent imperative for Australian policy to neither get ahead nor behind other nations, any momentum on releasing the records then appeared to grind to a halt. Australia never received any official indication from the United Kingdom of whether it would agree to release the records. As a memorandum in 1975 pointed out, External Affairs had last heard from the United Kingdom on the issue in September 1969. ${ }^{85}$ As a result, no decision had been apparently communicated to Japan on its 1965 request and nor had any further requests from Japan been presented when, in 1975, the issue finally became moot.

\section{Opening the Trials}

The decision to finally release the Australian trial proceedings to public access in 1975 appears to have been prompted not by Japan-which, sensibly, might have given up asking by then-but by Australian scholars such as Sissons pressing the Attorney-General's Department for access. Fortunately, at least as far as the Attorney-General's Department was concerned, some transition had taken place in how the records were viewed. In announcing his decision to lift the access restrictions, AttorneyGeneral Keppel Enderby QC pointed out, in fact, that he did not regard the trial proceedings as 'government records', as the 'conduct of these trials did not form a part of the normal administration' of government. ${ }^{86}$

83 'Borneo Story Still a Secret', Canberra Times (Canberra), 19 June 1969, 3. In fact, the book was not published for decades after this: Jack Wong Sue, Blood over Borneo (WA Skindivers Publications, c2001). 84 AH Borthwick for the Secretary, Ext Aff to the Secretary, Army, 15 July 1969, NAA: A1838, 3103/10/13/2 PART 15B.

85 WM Bush for the Secretary, Department of Foreign Affairs to the Secretary, Att Gen, 22 May 1975, NAA: A1838, 3103/10/13/2 PART 15B.

86 Att Gen press release, above n 7. 
This meant that the standard 30-year closed period then in force for archives—which would run until the early 1980s—did not apply. More crucially, Enderby remarked:

The Australian Government recognises the need of this and future generations of Australians to question and understand this country's past ... For too long Australian scholars have been hampered in their attempts to interpret Australiass history. Restrictions like this one no longer serve a useful purpose. They should be replaced by a policy based on open access wherever practicable. The past should be everyone's property. ${ }^{87}$

Given the general trend in the early 1970s to appreciate the value of government records to national history, and that other World War II-era records had been opened in 1971, the decision to make the trial proceedings accessible was probably not surprising. However, this decision may never have been made if the Attorney-General's Department had not acted without consultation with the Department of Foreign Affairs, as it now was. Presented with a fait accompli, Foreign Affairs complained about this 'unwelcome surprise', especially as it came on the eve of a ministerial visit to Japan. ${ }^{88}$ Foreign Affairs alleged that there were 'political considerations which, even after the passage of many years, remain[ed] strong' and argued that the United Kingdom should have been consulted as a matter of 'courtesy'. ${ }^{89}$ This reads as oddly deferential to the United Kingdom, given that there was no mention of consultation with the United States, which had earlier been of equal importance on this issue. Fortunately for scholars and the public, international consultation did not further delay the release of the records. Yet, clearly miffed at the Attorney-General's trespass on what it considered its patch of responsibility, Foreign Affairs sought an undertaking that, in the future, its concurrence should be sought before the Attorney-General's Department released 'historical records affecting other countries, ${ }^{90}$

It took close to a quarter of a century after the end of the Australian trials in 1951 for the Australian Government to finally make the trial proceedings publicly accessible. In the interim, most Australian trial participants had died, taking with them their invaluable personal accounts.

87 Ibid.

88 Department of Foreign Affairs to Tokyo, 6 June 1975, NAA: A1838, 3103/10/13/12 PART 16A.

89 JR Rowland to the Secretary, Att Gen, 6 June 1975; and Ext Aff File Note by W M Bush, 'Japanese War Criminals-Release of Records', 2 June 1975, both in NAA: A1838, 3103/10/13/12 PART 16A. 90 JR Rowland to the Secretary, Att Gen, 6 June 1975, NAA: A1838, 3103/10/13/12 PART 16A. 
Yet, even if Australia had granted any one of the Japanese requests for access to the trial proceedings in the 1950s and 1960s, any records that Australia provided to Japan would have been restricted from public access in Japan for another quarter century. It was not until 1999 that the Allied war crimes trials records gathered by the Ministry of Justice's Judiciary and Legislation Investigation Bureau were transferred to the National Archives of Japan, Tokyo, and made (mostly) accessible to the public. ${ }^{91}$ Fortunately for researchers, Japanese participants in the trials have left considerably more personal accounts in writing of their experiences at the Australian trials.

Today, the Australian trial proceedings are digitised in full at the National Archives of Australia, ${ }^{92}$ as are many other war crimes files. Fortunately, somewhere along the way Australia discarded the imperative not to get ahead of other Allied nations: Australia is, in fact, the only Allied nation thus far to disclose all its World War II war crimes trial proceedings online. Any researcher in the world can now access the trial proceedings, and efforts to make public comprehensive finding aids to the investigation and trial records are ongoing. While Australia has by its promotion of digitisation perhaps partially remedied the restrictions it placed for decades on historical research into the trials, the impact of the delay and particularly the loss of valuable firsthand accounts of the trials can never be overcome.

91 Totani, above $\mathrm{n} 4,188$.

92 Apart from a handful of large maps tendered as exhibits during the trials, the size of which currently precludes digitisation. 
This text is taken from The Court as Archive, edited by Ann Genovese, Trish Luker and Kim Rubenstein, published 2019 by ANU Press, The Australian National University, Canberra, Australia. doi.org/10.22459/CA.2019.06 